\title{
CLUSTER APPROACH TO AGRICULTURE EDUCATION IN RUSSIA BY THE EXAMPLE OF THE REPUBLIC OF TATARSTAN ${ }^{i}$
}

\author{
Bulat ZIGANSHIN, Kazan State Agrarian University, 420015, Karl Marx st, 65, Kazan; Russia, Republic of Tatarstan, \\ zigan66@mail.ru (corresponding author) \\ Renat ABDRAKHMANOV, Kazan State Agrarian University, 420015, Karl Marx st, 65, Kazan, Russia, Republic of Tatarstan \\ Ilnar GAYAZIEV, Kazan State Agrarian University, 420015, Karl Marx st, 65, Kazan, Russia, Republic of Tatarstan \\ Zufar ZAKIROV, Kazan State Agrarian University, 420015, Karl Marx st, 65, Kazan, Russia, Republic of Tatarstan
}

In modern conditions of rural development, the most important productive resource of the agrarian company is human capital. Only well-trained, receptive to innovation, adapted to the market economy, the technician can solve problems for the effective implementation of the economic activity of any enterprise. However, in recent years the problem of staffing is both a management and staff machine operators have intensified. Numbers have fallen substantially, increased the load on one specialist. Inadequate salaries and general social problems in rural areas of Russia and Republic of Tatarstan reduce the attractiveness of work for graduates of agricultural education institutions. The main purpose of this research was to develop a new conceptual approach to staffing of agro industrial complex in modern conditions. The subject of the study was the system of training personnel for agriculture of Russia (on the example Republic of Tatarstan).

The main methods used in this study are comparative theoretical-methodological research of educational institution and logical analyze agricultural education in Russia. The article discusses and analyzed the positive experience of scientific and educational cluster of agro-industrial complex of Republic of Tatarstan and Kazan State Agrarian University. One of the important conditions to solve some of the problems facing agriculture of Russia today, is the modernization of the agricultural education is associated with the formation of relevant scientific, scientific-educational and scientific-production platform. The progressive development of human potential of the agricultural sector plays an important role in achieving the designated high results as the main carrier of innovative knowledge and skills, without which the introduction of modern methods and technologies in production and management of enterprises of agroindustrial complex is simply impossible. Staffing issues agriculture is of great socio-economic importance and is the most important priorities of the state policy not only at present but in the future. Identified key staffing problems of the agro industrial complex of Russia and Tatarstan. Designed and proposed a new intensive model of development of scientific-educational cluster of agro-industrial complex of Republic of Tatarstan.

Keywords: agriculture, scientific-educational cluster(SEC), innovation, education, human resources, agro-industrial complex (AIC) of Republic of Tatarstan (RT), science-educational complex (SRC), Kazan State Agrarian University.

\section{INTRODUCTION}

Today, the agricultural sector of the Russian economy faces growing globalization of agricultural production and food market. XXI century is the century of high technologies and standards quality of life. Is the intensification of global competition, covering not only the traditional markets of goods, capital, technology and labor, but also of the system of national governance, support innovation, development of human capital.

The need to ensure food security in terms of population growth - today we are on a planet of 7 billion people - poses new challenges for agriculture. For the production of sufficient and safe agricultural products requires harmonization of the productive and ecological functions of agricultural landscapes, disease control and health protection of man, animals and plants, the sustainable development of rural areas and the desire of the population to achieve a new quality of life. Of particular concern is received wide spread production and use of genetically modified organisms (GMOs), carrying a serious risk for human and animal health, biological diversity on the planet. This requires special mechanisms and prevention, such as humanitarian expertise and agrobioethics (Nezhmetdinova, 2013; Faizrakhmanov et al., 2008).

In modern conditions of rural development the most important productive resource of the agrarian company is human capital. Only well-trained, receptive to innovation, adapted to the market economy, the technician can solve problems for the effective implementation of the economic activity of any enterprise (Faizrakhmanov, 2007; Faizrakhmanov et al., 2009). However, in recent years the problem of staffing of both management and mechanical staff

Copyright (C) 2017 The Authors. Published by Aleksandras Stulginskis University. This is an open-access article distributed under the terms of the Creative Commons Attribution License (CC-BY 4.0), which permits unrestricted use, distribution, and reproduction in any medium, provided the original author and source are credited. 
In Russian agro industrial complex has significantly deteriorated. Numbers have fallen substantially increased the workload per specialist. Requirements to the professional level, computer literacy, organizational skills significantly increased (Faizrakhmanov, 2012). Inadequate salaries and general social problems in rural areas of Russia and Republic of Tatarstan reduce the attractiveness of work for graduates of agricultural education institutions (The study of ...2010; Kozlov and Yakovleva, 2011; Gorbunova and Suslova, 2014; Nezhmetdinova, 2011).

There is a problem related to the absence in Russia of new approaches in training specialists in modern agricultural technologies. In this regard, the main purpose of this research was to develop a new conceptual approach to staffing of agro industrial complex in modern conditions. The subject of the study was the system of training personnel for agriculture of Russia (on the example Republic of Tatarstan). The main objectives of the research was the identification of effective mechanism of interaction of public authorities, employers and educational institutions in the agricultural sector; description of key approaches that must be developed by the government and municipal authorities, agricultural enterprises and agribusiness to increase attractiveness of rural labor for youth.

Currently, in the framework of the reform of vocational education in the Republic of Tatarstan has created a system of scientific-educational cluster on a sectoral basis (Faizrakhmanov, 2015; Nezhmetdinova, 2015). The essence of the concept of scientific-educational cluster - industry Association of universities, institutions of primary and secondary vocational education, vocational schools, key enterprises, key customers and consumers specialists, headed by a leading University in the relevant industry (Faizrakhmanov et al., 2008; Ivanov, 2009).

\section{RESEARCH METHODS}

The main methods used in this study are comparative theoretical-methodological research of educational institution and logical analyze agricultural education in Russia. Work on creation of the cluster working in the scientific and educational sphere of the agro industrial complex was started in 2006 April 28, 2011 was the first legal document, which defined the status and composition of the scientific and educational cluster of Kazan State Agrarian University (resolution of the Cabinet of Ministers of the Republic of Tatarstan dated 28.04.2011, No. 350) (Resolution of... No. 350, 2011). This decision was taken in order to improve the quality of education and the efficient use of labor resources. The main directions of improvement of forms and methods of training in accordance with the needs of employers in the sphere of agro-industrial complex, as well as creating a competitive environment for educational institutions, which train specialists in this area, the availability of vocational training for all categories of young people (Nezhmetdinova and Shagivaleev, 2014, Kurshin et al., 2009).

Geographical feature of the scientific and educational cluster of Kazan State Agrarian University is that the location of the institutions entering it can be conditionally divided into 5 zones that allow covering all 43 municipal districts of the Republic of Tatarstan.

In general, educational institutions as a part of a cluster solve the following problems:

a) increase in efficiency and quality of educational process;

b) support of adaptation of graduates to social, economic and cultural requirements of society and to changes of labor market;

c) increase in efficiency of use in operation of the intellectual, material and information resources;

d) establishment of cooperation communications with non-profit organizations and the enterprises in innovative sectors of economy;

e) the active use of the positive experience of scientific and educational activities, professional and pedagogical skill.

Educational institutions of a scientific and educational cluster of agrarian and industrial complex of the Republic of Tatarstan develop open multi-level educational programs for related agrarian specialties initial, average and higher education; providing an eligibility and abbreviation of periods of training within a cluster.

The role of the basic enterprises as a part of a cluster is that they annually create requests for switching on in the state order for training of workers and experts, direct the most perspective workers to additional professional education; carry out professional orientation operation at schools to provide a set.

In turn, it allows increasing quality and efficiency of staffing of agrarian and industrial complex of RT because the Kazan State Agrarian University can:

a) to send for operation to secondary vocational education institutions the faculty;

b) to organize pedagogical training of training officers and teachers of special disciplines for institutions of professional education of a cluster;

c) under contracts with the basic enterprises to organize research and development and experimental and experimental operation;

d) to analyze and monitor employment of graduates.

\section{RESEARCH RESULTS}

The main achievement over the years, scientific-educational cluster (SEC) of Kazan State Agrarian University is an increase in the proportion of students coming from institutions cluster. In 2011, it was $10.4 \%$ of the total number of students with secondary professional education in 2013 and $21.8 \%$, in 2014 - in the region of $30 \%$ of the total number of students with college. In recent years there has been a positive dynamics arriving in Kazan State Agrarian University, 
including students from secondary education. In the end of 2010 it was $26.9 \%$ - in $2014-37 \%$. This contributes to a large and diverse work of the Center for corporate-cluster training of Kazan State Agrarian University.

It is promoted by big and various work of the Center of corporate and cluster training of the Kazan State Agrarian University. Among them - holding the Olympic Games and competitions of professional skill:

The best by profession - "The tractor operator the driver of agricultural production"

Competition "Young Combine Operators"

The Olympic Games among students in "Mechanization of agriculture"

Intellectual game "The Beginning Farmer", etc.

Also important is the inclusion of students of secondary professional education of the scientific-educational cluster in real processes of production and realization of agricultural products. This work in the framework of practical training at the enterprises, participation in Russian and national measures to support agriculture, such as, for example, the annual Agricultural fair (Kozlov, 2009; Shalimov, 2010). Meanwhile, there are real problems with staffing the agricultural sector of Russia and the Republic of Tatarstan in the conditions of modern challenges (Proca N.A., 2012; Kozlov and Yakovleva, 2011; Gorbunova and Suslova, 2014).

Meanwhile, there are real problems with staffing of agrarian and industrial complex of Russia and the Republic of Tatarstan in the conditions of modern calls (Resolution of ..., No. 1394-R, 2011). In the agriculture representing one of the most important strategic directions of activity of the Russian society no more than $30 \%$ of graduates of agricultural higher education institutions annually go to work. As a rule, they studied in the budgetary form. Unfortunately, from them without having worked $14 \%$ and year, leave this sphere as practice shows, on less qualified, but more paid work. At the same time, 77. 3\% of graduates of the Kazan SAU in 2013 have gone to work in the specialty. The deficiency of experts only with the higher agrarian education, as a result, is about 80 thousand people in branch. At the same time, it is about key positions as the chief agronomists, livestock specialists, veterinarians, engineers and other experts.

Today staffing of agrarian and industrial complex of RT and activities of an agrarian scientific and educational cluster can face serious problems of both the objective, and subjective plan. We see seven key, from our point of view, problems of the agrarian and industrial complexes of Republic of Tatarstan interfering successful development of a scientific and educational cluster it:

1. An imbalance in training for agrarian and industrial complex on the colleges and university levels and insufficient communication with regional economy.

2. Feeble level of motivation at youth in a choice of future operation in agriculture, as a result of low prestige and level of the salary. For example, by the beginning of 2013 at more than a half of country people, including also young specialists, value of the average salary did not exceed 12-13 thousand rubles.

3. Limited financing of development of SEC (scientific and educational cluster) of agrarian and industrial complex of RT. It is carried out only at the expense of own financial resources of the educational institutions entering a scientific and educational cluster.

4. The low level of an involvement in operation of SEC of real customers from agricultural producers, their absence in governing bodies of a cluster.

5. Aging of research and educational personnel of SEC, loss of compliance of their level to the modern professional competences and requirements of innovative technologies in agriculture.

6. Infrastructure, educational-experimental farms, especially colleges, need serious upgrade, moral and material up-dating.

7. Absence at SEC of the uniform development strategy and road maps of educational institutions which have complex character seriously hinders, and even slows down their activities.

As a result, today within the existing conditions we have limited extensive model of development of a cluster where each element of a cluster interacts separately, and in this work is not present to the uniform strategy coordinated with the employer.

\section{CONCLUSIONS AND DISCUSSION}

For increase in overall performance of SEC of agrarian and industrial complex of Republic of Tatarstan and a new conceptual approach to staffing of agro industrial complex in modern conditions we offer the following:

1. To carry out the complex analysis of overall performance of secondary vocational education institutions of an agrarian profile for development of measures for minimization of an imbalance in training for agrarian and industrial complex.

2. To strengthen at the state level (The ministries and departments) a package of measures for involvement of youth on the village, including developments and implementation of the Republican program "We Will Return Youth on the Village", promoting of agrarian specialties among a city young people.

3. To introduce new models of financing and support (for example, research grants, effective contracts at the level of SPO), stimulation and support of investments from agro holding and agrobusiness (tax benefits, an endowment, etc. from the government of Republic of Tatarstan).

4. To include in the structure of governing bodies of Republic of Tatarstan agrarian and industrial complex SEC institutions of representatives of leading agricultural enterprises and agrobusiness. 
5. To create "The center of competences of agrarian professional education", with functions of increase and certification of qualification of employees of agrarian and industrial complex, with involvement of specific employers, on the basis of the Kazan State Agrarian University.

6. To fix curators - the large agricultural producers responsible for modernization of infrastructure of the SEC educational institutions.

7. To promote development of Strategy and the program of development of each educational institution, drawing up Road maps together with agricultural producers and agrobusiness.

8. To carry out annual monitoring of efficiency of measures of staffing of agrarian and industrial complex of Republic of Tatarstan with assistance of the Ministry of Agriculture and Food, the Ministry of Agriculture, the Ministry of Education and Science, the Ministry of Labour, employment and social protection by attraction of financial resources within State programs.

In our opinion, we need to take some drastic measures that will help to rebuild the model of development of scientific-educational cluster agro-industrial complex of the Republic of Tatarstan, where the employer will be included in the work at all stages of training. He will set criteria as at the entrance, acting as the customer, to participate at all stages of training, offering educational institutions not only qualitative, but that is not unimportant, qualifications and professional standards in the areas and level of training. At the final stage he acts as examiner of order frames, checking professional competence and quality of training. The intensive model of development of SEC of agrarian and industrial complex of RT is offered.

Thus, in SEC of agrarian and industrial complex of RT and the Kazan State Agrarian University, the wealth of experience in area of research and development and educational activities is accumulated, there is a unique scientific and technical and personnel potential, there are possibilities of preparation, retraining and professional development of frames in all main directions of agricultural production. At the same time, to raise prestige, the complex of serious measures at the state level, efforts of large agro holdings, and all participants of scientific and educational activities in an agrarian sector is necessary to increase attractiveness of operation in agriculture. Especially in it the agrarian scientific and educational cluster which main objective is increase in efficiency and quality of vocational training of experts through development of the continuous professional education with attraction in this process of direct employers shall take the place. Implementation of such structure will allow optimizing considerably costs of vocational training of frames, to create the uniform educational complex of agrarian and industrial complex providing improvement of quality and efficiency of agrarian education.

\section{REFERENCES}

1. Faizrakhmanov, D.I., Valiev A.R. 2007. The Integration of agricultural education and business. The Agribusiness of Tatarstan, No. 10 (12), pp. 48-51.

2. Faizrakhmanov, D.I., Valiev, A.R., Nezhmetdinova, F.T., Krupin, G.D. 2008. Agricultural scientific and educational potential of the Republic of Tatarstan and directions of its development. Vestnik of Kazan State Agrarian University, Vol. 3(9). pp. 5-10.

3. Faizrakhmanov D.I., Valiev, A.R., Ziganshin. B.G. 2009. Innovative model of effective interaction of state educational institutions and private businesses within industry clusters. Vestnik of Kazan State Agrarian University, Vol. 4(14), pp. 93-96.

4. Faizrakhmanov D.I., Valiev, A.R., Nezhmetdinova, F.T., Nizams, R.M, Khamidullin, N.N. 2012. Agrotechnopark as an innovative factor of increase of competitiveness of agriculture in conditions of Russia's entry into the WTO. Vestnik of Kazan State Agrarian University, Vol. 3 (25), pp. 50-58.

5. Faizrakhmanov, I.D., Nezhmetdinova, F.T., Valiev, A.R., Shagivaleev, L.R. 2015. Cluster approach to agricultural professional education in the Republic of Tatarstan. Development of system of professional-public accreditation of educational programs in agriculture in the Russian Federation. Collection of scientific works. - SPb.: FSBEI of Spbgau, pp. 109-117.

6. Gorbunova I.I., Suslova N.M. 2014. Staffing - the basis of sustainable development of rural areas. 2009. Journal of the proceedings of Tula state University. Economic and legal Sciences, No. 2-1, pp. 167. Available at: http://cyberleninka.ru/article/n/kadrovoeobespechenie-osnova-ustoychivogo-razvitiya-selskih-territoriy\#ixzz3IOMHfwAH (Accessed on 12/05/2017).

7. Ivanov, C. N. 2009. The partnership of agricultural businesses and education: innovations in management. Devyatkin So Century - Moscow: Finance and statistics, pp. 64. Available at: http://www.biblioclub.ru/index.php?page=book\&id=225548 (Accessed on 12/05/2017).

8. Kozlov A.V. 2009. Problems of formation of personnel policy in the agrarian sector of economy. Journal of the proceedings of Tula state University. Economic and legal Sciences, No. 2-1, pp. 60.

9. Kozlov, A.V., Yakovleva, O.A. 2011. Staffing agriculture: problems and prospects. Publishing FGOU of FPIC, Moscow.

10. Kurshin, O.A., Nezhmetdinova, F.T., Faizrakhmanov D.I. 2009. The development strategy of the Kazan state agrarian University until 2022: scientific publication. Edited D.I. Faizrakhmanov. Publishing house "Academy of Sciences. Kazan.

11. Nezhmetdinova, F.T. 2011. Improvement strategic development of vocational education of the Republic of Tatarstan in accordance with the requirements of modern society and innovative economy. Professional education in the 21 st century: a regional response to the challenges of modernization: monograph; Minister of education and science of the Russian Federation, Kazan state technological University, Kazan. pp. 99-177.

12. Nezhmetdinova F. 2013. Global challenges and globalization of bioethics. Croatian Medical Journal, Vol. 54(1), pp. 83-85. https://doi.org/10.3325/cmj.2013.54.83 
13. Nezhmetdinova F. T., Shagivaleev L. R. 2014. Life and professional strategies graduates of scientific and educational cluster agro-industrial complex of the Republic of Tatarstan. General. ed. D. I. Faizrahmanov. Publishing house of Kazan SAU, Kazan, pp.79-84, pp. 89-95.

14. Nezhmetdinova, F.T., Valiev, A.R. 2015 Factors and criteria of formation of career plans of graduates of agricultural universities (by the example of Kazan State Agrarian University). The development of the system of professional-public accreditation of educational programs in agriculture in the Russian Federation. "Development of public accreditation of agricultural programs in Russia (PacAgro)" (543902-TEMPUS-1-2013-1-SK-TEMPUS-SMGR): Collection of scientific works. - SPb.: FSBEI of Spbgau., pp. 59-69.

15. Nezhmetdinova, F.T., Tinchurina, L.M., Valiev A.R. 2015. Positive experience and problems of development of agrarian education in Russia. The development of the system of professional-public accreditation of educational programs in agriculture in the Russian Federation. "Development of public accreditation of agricultural programs in Russia (PacAgro)" (543902-TEMPUS-1-2013-1-SKTEMPUS-SMGR): Collection of scientific works. - SPb.: FSBEI of Spbgau, pp. 70-77.

16. Proca N.A. 2012. Monitoring of human capital in the agricultural sector. Journal of Education, Science and Production, Vol. 1. pp. 1-6.

17. Resolution of the Cabinet of Ministers of the Republic of Tatarstan 28 April 2011 No. 350 "About creation of scientific-educational cluster of Federal state budgetary educational institution of higher professional education Kazan state agrarian University.

18. Resolution of the Cabinet of Ministers of the Republic of Tatarstan dated 01.08.2011, No. 1394-R "Approval of the coordinating Council of scientific and educational clusters Kazan state agrarian University.

19. Shalimov, A.I. 2010. The role of public support personnel potential of the agricultural sector. Bulletin of the Orel State Agrarian University, Vol. 23, pp. 87.

20. The study of Fast Future: scientific-technical progress and labor market in the near future. 2010. Available at: http://gtmarket.ru/news/state/2010/01/15/2482 (Accessed on 12/05/2017).

21. The labor market in rural areas and its regulation. 2007. Ed. 2nd, supplemented. Irepress. Moscow.

22. Ziganshin, B.G., Valiev, A.R. 2008. Some aspects of improving the quality of agricultural education. International scientific exchanges as a means of integration of Russian education into the global cultural space / Materials of international scientificpractical conference. Kazan: Kazan state agrarian university. 256 p. 